УДК $621.9 .02(07)$

DOI: $\underline{\text { https://doi.org/10.36910/6775-2313-5352-2019-14-26 }}$

Швець С. В., к.т.н.

Сумський державний університет

\title{
ВПЛИВ СХЕМИ РІЗАННЯ ТА МЕТОДУ ФОРМОУТВОРЕННЯ НА КОНСТРУКЦЮЮ РІЗАЛЬНОГО ІНСТРУМЕНТА
}

У прочесі різання вирішуються дві задачі - видалення припуску та формування поверхні деталі з необхідними параметрами якості. Це вимагає визначення схеми різання $i$ методу утворення поверхні деталі. На цей час у літературі немає однозначного визначення цих понять. В роботі, в першу чергу, приділена увага цій проблемі. Також показано, що вихідна інструментальна поверхня може бути реальною поверхнею, яка обмежує калібрувальну частину інструмента і на якій знаходяться формоутворюючі різальні кромки або їх ділянки, що контактують з поверхнею деталі. А може утворюватися рухами різальних кромок у просторі, тобто кінематично. Припуск може розділятися на шари поверхнями, щчо огортають поверхню деталі з наступним подрібненням кожного такого шару, або поверхнями, які перетинають поверхню деталі з подальшим розділенням їх на стружку. Методів формоутворення лезовим інструментом також може бути два. Це або лінійний контакт, або точковий. Схеми різання і методи формоутворення у поєднанні з відносними рухами інструмента $i$ деталі та уявою інженера-конструктора створюють широкі можливості для утворення різних видів і типів різальних інструментів.

Ключові слова: схема, метод, формоутворення, припуск, деталь, контакт, лезо

Вступ. Термін «проектування» різального інструмента має два значення. По-перше, це вибір певного виду інструмента із наявного ряду для забезпечення потреб технологічного процесу. 3 іншого боку, він може означати створення такого інструменту, якого ще немає і не було [1-3].

У першому випадку йдеться про вибір виду і типу інструмента, його конструктивних параметрів, про якість калібрувальної частини та інструментальний матеріал [4, 5]. Тобто, про здатність певного виду інструмента забезпечити якість і точність обробленої поверхні деталі при найменшій собівартості процесу.

У другому випадку вирішується задача створення нового, не існуючого інструмента [4], або аналізу чи вдосконаленню умов формоутворення. При цьому доцільно утворення поверхні деталі розглядати як функціонування деякого механізму, що складається із двох ланок: поверхні деталі і вихідної інструментальної поверхні [5]. Відносний рух цих ланок такий, що вихідна інструментальна поверхня повинна торкнутися кожної точки поверхні деталі. Отже, вихідна інструментальна поверхня, рухаючись по заданій траєкторії формує поверхню деталі. Якщо відомі поверхня деталі і траєкторія відносного (формоутворюючого) руху, то $\epsilon$ можливість вибудувавши іншу ланку, вихідну інструментальну поверхню, перетворити іiі на різальний інструмент.

Отже, необхідно дослідити вплив методу формоутворення і схеми різання на конструкцію різального інструмента. При цьому у літературі немає однозначного визначення цих понять, які можна застосувати до всіх інструментів [6-10]. Визначення одинарної чи групової схеми різання для протяжки не можливо застосувати до переважної кількості інших інструментів. Те саме відбувається і з профільним чи генераторним методом формоутворення.

Мета роботи - вдосконалення визначень схеми різання та методу формоутворення та дослідження їх впливу на конструкцію різального інструмента.

\section{1. Визначення схеми різання і методу формоутворення}

Робота різального інструменту полягає у видаленні 3 заготовки якоїсь частини матеріалу (припуску) з метою утворення необхідної форми поверхні деталі. Тому у процесі різання вирішуються дві задачі. Перша полягає у поборюванні опору руйнуванню матеріалу заготовки та забезпечення тривалості цього процесу відповідно до економічної доцільності (взаємодія із припуском). Друга - це формування поверхні деталі з необхідними параметрами якості. Ці задачі, що виникають перед різальним інструментом, вказують на наявність схем різання і методів утворення поверхонь деталей.

Схема різання показує в якій послідовності припуск подрібнюється на стружку [11]. За першою схемою його можна видаляти шарами 3 поверхнями за формою наближеними до 
форми поверхні деталі (огортають іiі), з наступним розділенням на більш мілкі елементи. А можна (друга схема) припуск спочатку розрізувати поверхнями, які перетинають поверхню деталі, і тільки потім утворені об'єми подрібнювати на стружку. Отже, можуть бути дві схеми різання.

Метод утворення поверхні вказує на те яким геометричним примітивом формується поверхня деталі [1]. Поверхня деталі може створюватися точкою, лінією або поверхнею. При використанні лезового різального інструмента, коли поверхня деталі утворюється у результаті видалення подрібненого припуску, формоутворення поверхні деталі можливе точкою або лінією.

Умовно можна вважати, що формоутворення поверхнею може відбуватися при використанні абразивного інструмента, якщо припустити, що видалення припуску відбувається завдяки взаємодії матеріалу заготовки з суцільною поверхнею інструмента, що утворена великою кількістю абразивних зерен-різців. Формоутворення поверхнею можливе при інших видах обробки, таких як: виливання, штампування, електроерозія.

\section{2. Ланки механізму формоутворення}

Отже, є дві схеми різання і два методи формоутворення, але при цьому існує велика кількість видів і типів різальних інструментів.

Вихідна інструментальна поверхня обмежує калібрувальну частину інструмента. Якщо різальна і калібрувальна частини чітко розмежовуються, то схема різання впливає на конструкцію різальної частини, а метод формоутворення - калібрувальної. Це не стосується інструментів у яких робоча частина на різальну і калібрувальну не поділяється. Наприклад, циліндрична фреза. Вихідна інструментальна поверхня циліндричної фрези із гвинтовим зубом це круговий циліндр, утворений рухом різальної кромки по колу. Але в кожний момент часу цей інструмент з поверхнею деталі має точковий контакт.

Основні види інструментів складають деяку множину

$$
\mathrm{W}=\left\{\mathrm{W}_{1}, \mathrm{~W}_{2}, \mathrm{~W}_{3}, \mathrm{~W}_{4}, \mathrm{~W}_{5}, \mathrm{~W}_{6}, \mathrm{~W}_{7}, \mathrm{~W}_{8}, \mathrm{~W}_{9}\right\} \text {, }
$$

де $\mathrm{W}_{1}$ - різці ; $\mathrm{W}_{2}$ - протяжки; $\mathrm{W}_{3}$ - фрези; $\mathrm{W}_{4}$ - свердла; $\mathrm{W}_{5}$ - зенкери; $\mathrm{W}_{6}$ розвертки; $\mathrm{W}_{7}$ - мітчики; $\mathrm{W}_{8}$ - плашки; $\mathrm{W}_{9}$ - зуборізний інструмент.

Чіткої межі між ними не існує. Різні види інструментів об'єднуються у групи, утворюючи немов би новий вид. Так говорять про зуборізний інструмент, до складу якого входять різці, фрези, протяжки і притаманні тільки обробці зубчастих коліс довбачі. Для нарізування різі використовуються різці, фрези, мітчики, плашки. Свердло, оснащене багатогранною непереточуваною пластиною загального призначення, може використовуватися як розточувальний різець. Тому види поділяються на типи, які, завдяки вдосконаленню виробництва, змінюються та розвиваються.

У процесі утворення деталі значний внесок належить рухам. При необхідності рух $\epsilon$ складовою утворення вихідної інструментальної поверхні (його можна назвати допоміжним), а коли вихідна інструментальна поверхня утворена іï рух відносно поверхні деталі $\epsilon$ формоутворюючим.

Вихідна інструментальна поверхня може мати таку траєкторію, що множина ліній контакту послідовно формує поверхню деталі, а може її рух імітувати рух парної деталі, яка має контактувати з оброблюваною деталлю в майбутньому вузлі машини.

Досить часто прості рухи, такі як прямолінійно-поступальний i обертальний, відтворюються конструктивно. Наприклад, обертання навколо своєї осі черв'ячної фрези, завдяки гвинтовій поверхні черв'яка, створює ситуацію поступального руху рейки відносно колеса при його обертанні.

Обертання циліндричної фрези з гвинтовими зубами переміщує точку контакту вздовж осі фрези утворюючи, при точковому контакті, кінематичну характеристику. Контакт між ланками механізму формоутворення лінійний, і ця лінія - характеристика. Але, як зазначено вище, маємо два методи утворення поверхні деталі різальним інструментом - лінією і точкою. Тоді, для дотримання умов формоутворення при точковому контакті, характеристика створюється кінематично [12].

Формоутворююча точка або лінія (різальна кромка) розміщуються на вихідній інструментальній поверхні.

Вихідна інструментальна поверхня може бути відтворена геометрично у вигляді поверхні, яка обмежує калібрувальну частину інструмента i на якій знаходяться формоутворюючі різальні кромки або їх точки, що контактують 3 поверхнею деталі. А може 
утворюватися різальними кромками (навіть простими за формою) чи їх точками за складних додаткових їх рухів у просторі, тобто, як і характеристика, кінематично.

Якщо характеристика і вихідна інструментальна поверхня кінематичні, то для їх створення потрібні додаткові рухи. Механізм формоутворення складається із вихідної інструментальної поверхні, поверхні деталі та їх відносного руху, руху формоутворення.

Отже, рухи поділяються на формоутворюючі і на допоміжні, такі, які створюють кінематичну вихідну інструментальну поверхню.

Тому і схема різання, і метод утворення поверхні впливають на конструкцію різального інструмента. Але, крім цього, важливе значення мають траєкторії рухів цих геометричних примітивів (точки або лінії), які формують поверхню деталі.

\section{інструментів}

3. Схеми різання і методи формоутворення при використанні різних видів

3.1 При точінні прохідний різець здійснює точковий контакт (рис. 1 a), вихідна інструментальна поверхня при цьому утворюється кінематично. ІІї можна уявити як циліндр, що насувається на поверхню деталі [12]. Тобто, вона залежить від обертального, $D r$, i поступального рухів, $D s$. А можна уявити і як площину, в якій в кожний момент часу лежать вектор швидкості обертального руху, $V r$, і вектор швидкості поступального, $V s$.

Відрізувальний і підрізувальний різці (рис. 16, в) контактують 3 поверхнею деталі в точці [7 - 9]. Вихідна інструментальна поверхня утворюється завдяки рухові вершини різця по спіралі. Утворення поверхні деталі можна уявити як обертання по колу прямої лінії, що утворюється прямолінійним рухом вершини різця до осі деталі.

Причому, якщо при використанні прохідного різця вихідна інструментальна поверхня може бути утворена як обертанням прямої лінії по колу, так і рухом кола вздовж прямої лінії,

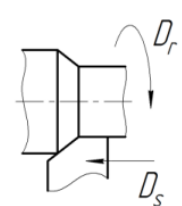

a)

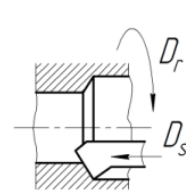

e)
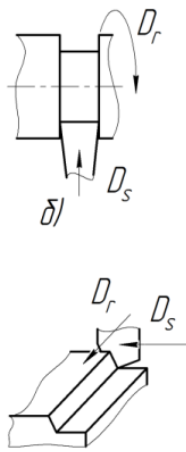

E)
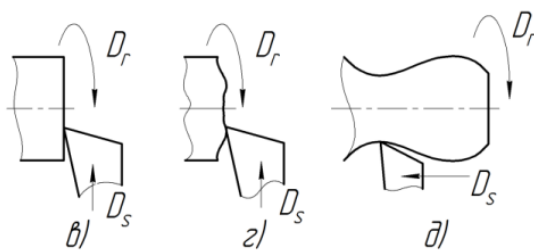

()

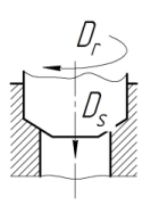

*)
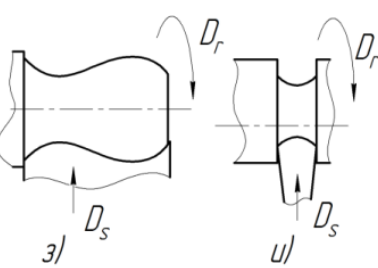

Рис. 1. Формоутворення точкою та лінією

то у випадку з відрізним чи підрізним різцями вона можлива тільки при русі точки по спіралі. Тобто утворюється поверхня (площина), в якій лежать вектори швидкостей обертального і поступального рухів.

Точіння фасонного торця (рис. 1 г) можливе при змінюванні напряму вектора швидкості руху подачі.

Точіння поверхні, показаної на рис. 1 д, можна розглядати як насування еластичної вихідної інструментальної поверхні на поверхню деталі. У цьому випадку вона утворюється завдяки незмінному рухові подачі, $D s$, і змінюваній траєкторії обертання, $D r$. Проте, ії можна уявити і як поверхню, до якої в кожний момент часу дотичні вектори швидкостей обертального, $V r$, і поступального, $V s$, рухів.

Отже, у всіх розглянутих випадках, спільним $є$ те, що при точковому контакті існує кінематична вихідна інструментальна поверхня, залежна від координат векторів швидкостей обертального і поступального рухів у кожній ії точці і збігається з поверхнею деталі.

(рис. $1 \%$ ).

Це стосується також і розточування (рис. 1 e), свердління, зенкування і розвертування

При струганні (рис. $1 \epsilon$ ) обертальний рух перетворюється на прямолінійний, $r \rightarrow \infty$, тому поверхня обертання перетворюється на площину.

При роботі фасонного різця (рис. 1 3) маємо реальну вихідну інструментальну поверхню. При лінійному контакті, а саме так через різальну кромку контактує з поверхнею 
деталі фасонний різець, одна із ії координатних ліній уже існує. Тобто, коли є твірна, конструктор задає форму напрямної (коло чи пряма лінія) і утворюється реальна вихідна інструментальна поверхня круглого чи призматичного різця.

При лінійному контакті форма лінії контакту (твірної вихідної інструментальної поверхні) визначається формою поверхні деталі та бажаною орієнтацією у просторі. Напрямну призначає конструктор. Тому це реальна поверхня, iї параметри від рухів у процесі утворення деталі не залежать.

Канавочний різець (рис. 1 u) має дві вихідні інструментальні поверхні - реальну і кінематичну. По дну канавки відбувається лінійний контакт, а на бічних поверхнях - точковий.

Щоб спроектувати різальний інструмент на підставі визначення вихідної інструментально поверхні необхідно визначити іiі координатні лінії. При лінійному контакті одна із цих ліній і є твірною, а напрямну пропонує конструктор. Якщо реально існує одна із координатних ліній, то утворюється реальна вихідна інструментальна поверхня. У випадку точкового контакту, координатні лінії утворюються кінематично, тому створюється можливість утворення безлічі форм вихідної інструментальної поверхні (табл.1). Тобто функціонального зв'язку між формами поверхні деталі і вихідної інструментальної поверхні не існує. I це вказує на великі можливості в конструюванні різальних інструментів.

3.2 При фрезеруванні (рис. $2 a, \sigma, 6$ ) припуск розподіляється на стружку поверхнями, що перетинають поверхню деталі. Іноді, для більшого подрібнення і таких утворених стружок, на різальних кромках створюють стружкоподільні канавки. Така послідовність видалення припуска вказує на другу схему різання.

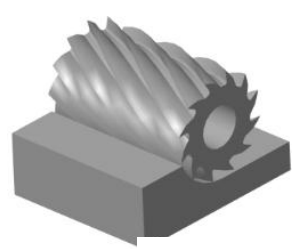

a)

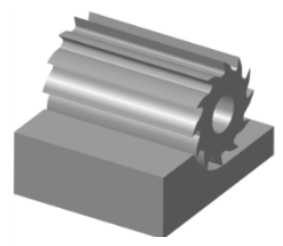

б)

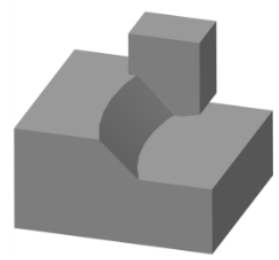

в)

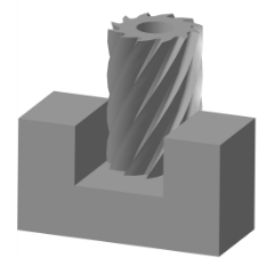

2)

Рис. 2. Схеми різання та умови контакту при фрезеруванні

Стосовно методу утворення поверхні, то циліндричні фрези із гвинтовими зубами мають точковий контакт з поверхнею деталі (рис. 2 a), а 3 прямими - лінійний (рис. 2 б). У цих фрез повністю збігається форма вихідної інструментальної поверхні (циліндр), але, залежно від форми різальної кромки, змінюються умови контакту, тобто метод формоутворення.

Торцева фреза (рис. 2 в) контактує 3 поверхнею деталі площиною, яка утворюється точковим контактом вершин іiі зубів.

Кінцева фреза (рис. 2 г) поєднує в собі схеми зрізування припуску і методи утворення поверхні циліндричної і торцевої фрези, тому що частина ії вихідної інструментальної поверхні циліндр, а частина - площина.

Дискова фреза при відрізуванні має точковий контакт і відтворює другу схему різання.

3.3 Відомо, що схема зрізування шарів при роботі протяжки істотно впливає на конструкцію різальної частини інструменту і на його стійкість [6, 13 - 17]. Схема показує, яким чином і у якій послідовності весь припуск розподіляється між зубами протяжки. Припуск при протягуванні максимально зрізується чорновою секцією, тому конструктивні особливості переважно стосуються сама іiі.

Існують дві схеми. Перша, коли припуск розподіляється по шарам рівномірно між усіма зубами, а потім кожний шар подрібнюється стружкоподільними канавками (рис. 3 a). Поверхні, що розмежовують шари, огортають поверхню деталі. Така схема має назву «одинарна схема
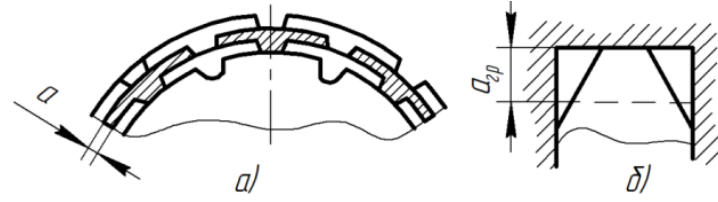

Рис. 3. Схеми різання при протягуванні різання». Друга - передбачає подрібнення шару товщиною $a_{2 p}$ (рис. 3 б) на стружку поверхнями, що перетинають поверхню деталі. При цьому $a_{2 p}$ це тільки частина припуску, яка зрізується групою зубів. Звичайно у групі два або три зуби. Може бути чотири і більше, але все залежить від умов 
стружкоутворення і велика кількість зубів у групі використовується рідко. Проходить 1-й зуб групи, за ним 2-й і т. д. Така схема дістала назву «групова схема різання».

Відповідно конструкції протяжок групового і одинарного різання відрізняються. Навіть одна і та сама схема різання для одного виду інструмента може бути реалізована завдяки різним конструктивним рішенням (табл.1).

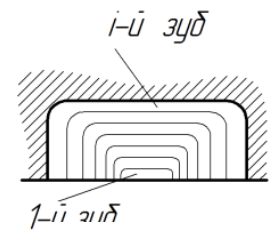

a)

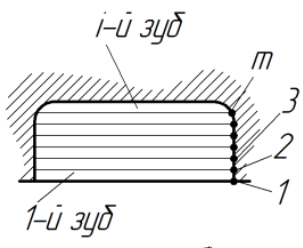

б)

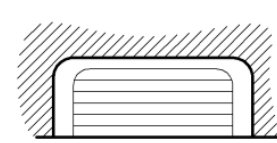

в)

Рис. 4. Методи утворення поверхонь при протягуванні

При протягуванні може реалізовуватися лінійний контакт (профільний метод) або точковий (генераторний метод). Звичайно лінійний контакт (рис. $4 a$ ) дозволяє отримати більш якісну поверхню, точковий (рис. 4 б) - підвищити стійкість інструмента. Через це, іноді комбінують методи (рис. 3 в).

Калібрувальна секція відділяє шари поверхнею, що збігається 3 поверхнею деталі. Тому це і $є$ вихідна інструментальна поверхня. Рухаючись у заданому напрямі вона, завдяки розміщеним на ній різальним кромкам, формує поверхню деталі. Характеристика реальна, відповідає різальній кромці зуба калібрувальної секції.

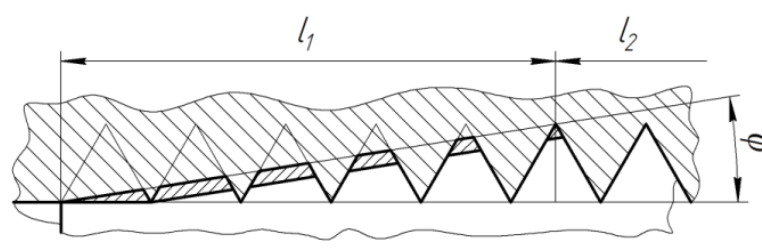

Рис. 5. Схема формоутворення мітчиком

3.4 При роботі мітчика припуск різальною частиною 3 кутом $\varphi$ (в межах $l_{1}$, рис. 5) розділяється послідовно поверхнями, що перетинають поверхню деталі. Це вказує на другу схему різання. На калібрувальній частині, $l_{2}$, різальні кромки, які відповідають профілю різі, повністю контактують 3 поверхнею деталі. Отже метод утворення поверхні - лінійний (табл.1). Так само формується поверхня різі і при роботі плашки.

3.5 При нарізуванні конічних коліс 3 круговими зубами (рис. 6) відтворюється відповідна передача. Метод базується на принципі обкочування заготовки по твірному колесі [1], зубом якого є різець голівки, що формує западину на заготовці.

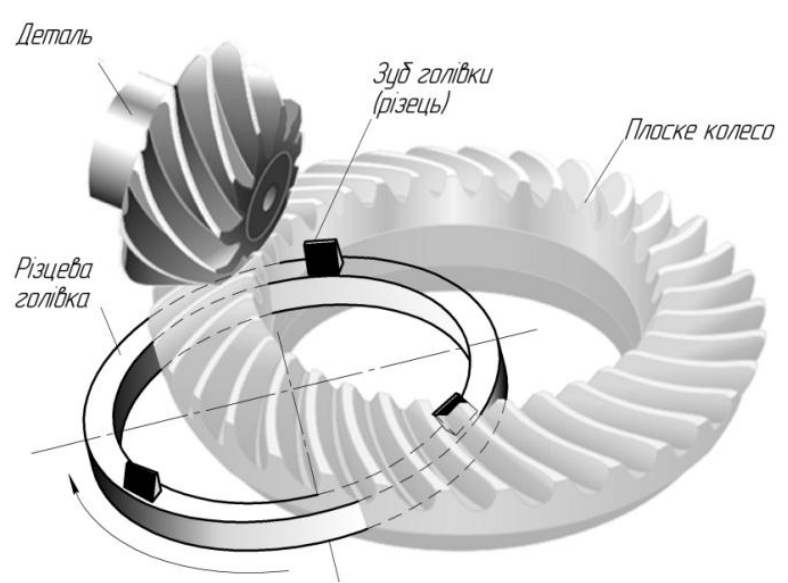

Рис. 6. Схема нарізування конічних коліс $з$ круговим зубом

Профіль зуба деталі утворюється як обвідна послідовних положень прямолінійного профілю різця. Огинання здійснюється за рахунок погодженого обертання заготовки та уявного твірного колеса. Роль твірного колеса у зуборізному верстаті відіграє спеціальна люлька, по напрямній якої переміщається різцева голівка.

Вихідна інструментальна поверхня, це парне колесо до конічного колеса 3 круговими зубами. Профіль зуба деталі утворюється як обвідна послідовних положень прямолінійного профілю різця. Тобто, маємо точковий контакт різального інструмента 3 поверхнею деталі (табл.1).

Тому для утворення лінійного контакту (характеристики) використовується кругова подача (обкочування). Цей кінематично утворений профіль розповсюджується на усю поверхню зуба конічного колеса завдяки обертальному руху головки зі швидкістю різання.

Форма різальної кромки різця впливає на координати точок контакту різального інструмента 3 поверхнею деталі, тобто на профіль зуба деталі, а частота обертання головки на щільність траєкторій формотвірних точок, тобто на якість обробленої поверхні.

Вихідна інструментальна поверхня утворюється точками відповідної форми різальної кромки різця завдяки узгодженим обертальним рухам умовного парного колоса та заготовки i незалежного обертального руху різцевої головки. 
Таблиця 1

Вплив виду і типу інструмента на схему різання і умови контакту з поверхнею деталі (метод формоутворення)

\begin{tabular}{|c|c|c|c|c|c|c|c|c|c|c|c|c|c|}
\hline \multicolumn{2}{|c|}{ Інструмент } & \multicolumn{2}{|c|}{$\begin{array}{l}\text { Схе- } \\
\text { ма } \\
\text { різан } \\
\text {-ня }\end{array}$} & \multicolumn{2}{|c|}{$\begin{array}{l}\text { Кон- } \\
\text { такт }\end{array}$} & \multicolumn{2}{|c|}{$\begin{array}{l}\text { Харак- } \\
\text { терис- } \\
\text { тика }\end{array}$} & \multicolumn{2}{|c|}{$\begin{array}{c}\text { Вихід- } \\
\text { на } \\
\text { інстру- } \\
\text { мен- } \\
\text { тальна } \\
\text { повер- } \\
\text { хня }\end{array}$} & \multicolumn{2}{|c|}{$\begin{array}{l}\text { Голов- } \\
\text { ний } \\
\text { рух } \\
\text { різан- } \\
\text { ня }\end{array}$} & \multicolumn{2}{|c|}{$\begin{array}{c}\text { Рух } \\
\text { подачі }\end{array}$} \\
\hline Вид & Тип & 1 & 2 & 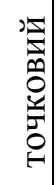 & 罚 & 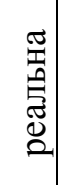 & 兽泀 & 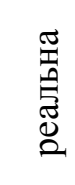 & 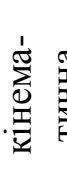 & 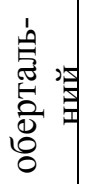 & 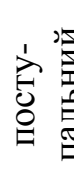 & 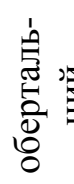 & 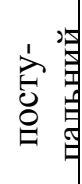 \\
\hline \multirow{3}{*}{ Різці } & обточувальні & & $\mathrm{x}$ & $\mathrm{x}$ & & & $\mathrm{x}$ & & $\mathrm{x}$ & $\mathrm{x}$ & & & $\mathrm{x}$ \\
\hline & розточувальні & & $\mathrm{x}$ & $\mathrm{x}$ & & & $\mathrm{x}$ & & $\mathrm{x}$ & $\mathrm{x}$ & & & $\mathrm{x}$ \\
\hline & фасонні & $\mathrm{x}$ & & & $\mathrm{x}$ & $\mathrm{x}$ & & $\mathrm{x}$ & & $\mathrm{x}$ & & & $\mathrm{x}$ \\
\hline \multirow{5}{*}{ Фрези } & $\begin{array}{l}\text { циліндрична } \\
\text { прямозуба }\end{array}$ & & $\mathrm{x}$ & & $\mathrm{x}$ & & & $\mathrm{x}$ & & $\mathrm{x}$ & & & $\mathrm{x}$ \\
\hline & $\begin{array}{l}\text { циліндрична } \\
\text { косозуба }\end{array}$ & & $\mathrm{x}$ & $\mathrm{x}$ & & & $\mathrm{x}$ & $\mathrm{x}$ & & $\mathrm{x}$ & & & $\mathrm{x}$ \\
\hline & торцева & & $\mathrm{x}$ & $\mathrm{x}$ & & & $\mathrm{x}$ & $\mathrm{x}$ & & $\mathrm{x}$ & & & $\mathrm{x}$ \\
\hline & кінцева & $\mathrm{x}$ & $\mathrm{x}$ & $\mathrm{x}$ & $\mathrm{x}$ & & $\mathrm{x}$ & $\mathrm{x}$ & & $\mathrm{x}$ & & & $\mathrm{x}$ \\
\hline & дискова & & $\mathrm{x}$ & $\mathrm{x}$ & & & $\mathrm{x}$ & $\mathrm{x}$ & & $\mathrm{x}$ & & & $\mathrm{x}$ \\
\hline \multirow{2}{*}{ Протяжки } & одинарна & $\mathrm{x}$ & & & $\mathrm{x}$ & $\mathrm{x}$ & & $\mathrm{x}$ & & & $\mathrm{x}$ & & $\mathrm{x}$ \\
\hline & групова & & $\mathrm{x}$ & $\mathrm{x}$ & & & $\mathrm{x}$ & $\mathrm{x}$ & & & $\mathrm{x}$ & & $\mathrm{x}$ \\
\hline Свердла & & & $\mathrm{x}$ & $\mathrm{x}$ & & & $\mathrm{x}$ & $\mathrm{x}$ & & $\mathrm{x}$ & & & $\mathrm{x}$ \\
\hline Зенкери & & & $\mathrm{X}$ & $\mathrm{x}$ & & & $\mathrm{x}$ & $\mathrm{x}$ & & $\mathrm{x}$ & & & $\mathrm{x}$ \\
\hline Розвертки & & & $\mathrm{x}$ & $\mathrm{x}$ & & & $\mathrm{x}$ & $\mathrm{x}$ & & $\mathrm{x}$ & & & $\mathrm{x}$ \\
\hline \multirow{3}{*}{$\begin{array}{l}\text { Різенарізу- } \\
\text { вальні }\end{array}$} & плашка & & $\mathrm{x}$ & & $\mathrm{x}$ & & $\mathrm{x}$ & $\mathrm{x}$ & & $\mathrm{x}$ & & & $\mathrm{x}$ \\
\hline & мітчик & & $\mathrm{x}$ & & $\mathrm{x}$ & & $\mathrm{x}$ & $\mathrm{x}$ & & $\mathrm{x}$ & & & $\mathrm{x}$ \\
\hline & $\begin{array}{l}\text { голівка для } \\
\text { вихрового } \\
\text { фрезерування }\end{array}$ & & $\mathrm{x}$ & & $\mathrm{x}$ & & $\mathrm{x}$ & & $\mathrm{x}$ & $\mathrm{x}$ & & $\mathrm{x}$ & $\mathrm{x}$ \\
\hline \multirow{6}{*}{$\begin{array}{l}\text { Зубонарі- } \\
\text { зувальні }\end{array}$} & дискова фреза & & $\mathrm{x}$ & & $\mathrm{x}$ & $\mathrm{x}$ & & $\mathrm{x}$ & & $\mathrm{x}$ & & & $\mathrm{x}$ \\
\hline & $\begin{array}{l}\text { зубодовбальн } \\
\text { а голівка }\end{array}$ & & $\mathrm{x}$ & & $\mathrm{x}$ & $\mathrm{x}$ & & $\mathrm{x}$ & & & $\mathrm{x}$ & & $\mathrm{x}$ \\
\hline & довбач & $\mathrm{x}$ & & $\mathrm{x}$ & & $\mathrm{x}$ & & $\mathrm{x}$ & & & $\mathrm{x}$ & $\mathrm{x}$ & \\
\hline & $\begin{array}{l}\text { червячна } \\
\text { фреза }\end{array}$ & $\mathrm{x}$ & & $\mathrm{x}$ & & $\mathrm{x}$ & & $\mathrm{x}$ & & $\mathrm{x}$ & & & \\
\hline & $\begin{array}{l}\text { система для } \\
\text { конічних } \\
\text { коліс } 3 \\
\text { круговим } \\
\text { зубом } \\
\end{array}$ & $\mathrm{x}$ & & & $\mathrm{x}$ & & $\mathrm{x}$ & & $\mathrm{x}$ & $\mathrm{x}$ & & $\mathrm{x}$ & \\
\hline & $\begin{array}{l}\text { система для } \\
\text { конічних } \\
\text { коліс } 3 \\
\text { прямим зубом }\end{array}$ & $\mathrm{x}$ & & $\mathrm{x}$ & & & $\mathrm{x}$ & & $\mathrm{x}$ & & $\mathrm{x}$ & $\mathrm{x}$ & \\
\hline
\end{tabular}

3.6 Нарізування конічних прямозубих коліс відбувається на зубостругальних верстатах. У процесі нарізування зуб заготовки обробляється з двох сторін за допомогою двох зуборізних різців (рис. 7). За твірне тут прийнято парне колесо. 


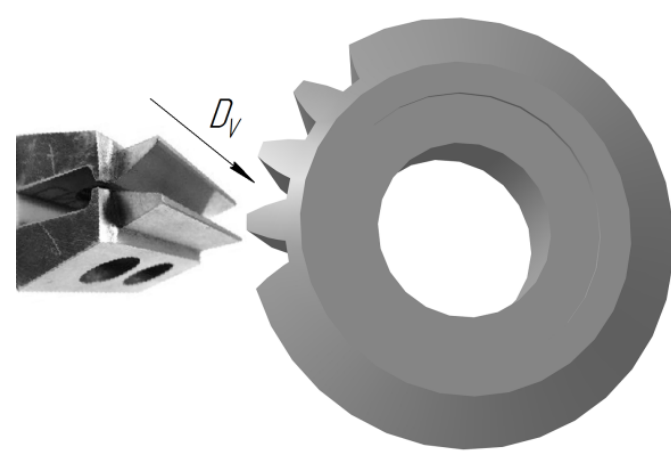

Рис. 7. Схема нарізування конічних прямозубих коліс

При нарізуванні конічних коліс 3 прямими зубами використовуються різці, що рухаються по прямолінійній траєкторії і мають точковий контакт 3 поверхнею деталі. Вихідна інструментальна поверхня, це поверхня парного колеса. Точки різальних кромок різців, завдяки кінематичній імітації обкочування, утворюють профіль зуба деталі (твірну), а прямолінійний рух різців вздовж поверхні зуба деталі утворює напрямну його поверхні.

При точковому контакті різального інструмента 3 поверхнею деталі твірна поверхні деталі в обох випадках утворюється узгодженим обертальними рухами, а напрямна - залежно від напряму зубів (табл.1).

Отже, вихідна інструментальна поверхня утворюється залежно від методу утворення поверхні деталі (контакт лінійний чи точковий). Якщо контакт лінійний, то тоді характеристика (різальна кромка) сприймається як твірна і далі необхідно запропонувати форму напрямної. Круглий фасонний різець: твірна - різальна кромка, напрямна - коло. Призматичний фасонний різець: твірна - різальна кромка, напрямна - пряма лінія. Протяжка: твірна - різальна кромка, напрямна пряма лінія у лінійних протяжок і коло у кругових.

Схема різання навіть змінює тип інструмента. Так послідовне розподілення припуску між чорновими зубами протяжки 3 наступним розрізуванням кожного шару стружкоподільними канавками, утворює одинарну протяжку, а заглиблення у припуск на однакову задану глибину групи зубів з наступним розділенням об'єму метала між зубами групи по ширині - групову.

Висновки. Схема різання визначає послідовність перетворення припуска на стружку. Ïх може бути дві. Припуск може розділятися на шари поверхнями, що огортають поверхню деталі з наступним подрібненням кожного такого шару - перша схема. Друга схема передбачає поділення припуска на шари поверхнями, які перетинають поверхню деталі 3 подальшим розділенням їх на стружку. При роботі лезового інструмента методів формоутворення також може бути два. Метод формоутворення визначає умови контакту різальної кромки з поверхнею деталі. Якщо вона повністю контактує 3 поверхнею деталі, то це буде лінійний метод формоутворення. Якщо контакт відбувається на невеличкій ділянці різальної кромки, то це точковий метод формоутворення. На цей час більшість різальних інструментів працюють за другою схемою різання (табл. 1). Першу схему різання використовує фасонний різець, одинарна протяжка і зубообробний інструмент, який імітує обкочування.

Вихідна інструментальна поверхня може бути реальною поверхнею, а може створюватися кінематично. Більшість видів різальних інструментів мають реальну вихідну інструментальну поверхню на якій знаходяться формоутворюючі кромки або точки (за винятком обточувальних і розточувальних різців, та складних механізмів: голівка для вихрового нарізування різі, системи для нарізування конічних коліс).

Вибір схеми різання і методу формоутворення 3 урахуванням рухів інструмента відносно поверхні деталі впливає на конструкцію різального інструмента. При цьому може використовуватися в якості вихідної інструментальної поверхні реальна поверхня або створена кінематично. Це розширює можливості при визначенні остаточних конструкцій різального інструмента. Визначення форми вихідної інструментальної поверхні (реальної чи кінематичної) не дає однозначного вирішення щодо конструкції різального інструмента. Після ії визначення настає евристичний етап роботи конструктора.

Дві схеми різання і два методи формоутворення у поєднанні з відносними рухами інструмента і деталі та уявою інженера-конструктора створюють широкі можливості для утворення різних видів і типів різальних інструментів.

\section{Інформаційні джерела:}

1. Семенченко И. И. Проектирование металлорежущих инструментов / И.И. Семенченко, В М Матюшин, Г. Н. Сахаров. - Москва: Машгиз, 1963. - 949 с. 
2. Bouzakis K.-D. A Critical Review of Characteristic Techniques for Improving the Cutting Performance of Coated Tools / K.-D. Bouzakis, G. Skordaris, E. Bouzakis, T. Kotsanis, P. Charalampous. - Journal of Machine Engineering, Vol. 17, No. 2, 2017. - Pp. 25 - 44.

3. Nee J. Fundamentals of Tool Design, SME, $2017-464$ pp.

4. Matuszak J. Computer aided design of cutting tools / J. Matuszak, M. Barszczю. - Advances in Science and Technology Research Journal, Vol. 9, No. 28, 2015. - Pp 107-111.

5. Родин П.Р. Основы формообразования поверхностей резанием / П.Р.Родин. - Киев: Вища школа, 1977. - 192 с.

6. Кукляк М.Л. Металорізальні інструменти. Проектування / М.Л. Кукляк, І.С. Афтаназів, I.I. Юрчишин - Львів: Львівська політехніка, 2003. - 556 с.

7. Pavani P. N. L. Experimental Study \& Optimization of Machining Parameters in Turning of AISI 1040 Steel with Micro-grooved WC Cutting Tools / P. N. L. Pavani, C. L. V. R. S. V. Prasad, K. Ramji. - Engineering Journal Volume 21 Issue 4, 2017. - Pp. 155-169.

8. Chudy R. Investigation of sequential machining processes in terms of power consumption and surface quality / R. Chudy, W. Grzesik. - Journal of Machine Engineering, Vol. 16, No. 3, 2016. Pp. 67- 74 .

9. Brecher Ch. Increasing productivity of cutting processes by real-time compensation of tool deflection due to process forces / Ch. Brecher, A. Wetzel, Th. Berners, A. Epple. - Journal of Machine Engineering, 2019, Vol. 19, No. 1. - Pp. 16-27.

10.Воронцов А. Л. Теоретические основы обработки металлов в машиностроении / А. Л. Воронцов, А. Ю. Албагачиев, Н. М. Султан-заде. - Старый Оскол: ТНТ, 2017. - 552 с.

11.Лашнев С. И. Геометрическая теория формирования поверхностей режущими инструментами / С.И.Лашнев, А.Н.Борисов, С.Г.Емельянов; под ред. Лашнева С.И. -Курск: Курск. гос. техн. ун-т, 1997. $-391 \mathrm{c}$.

12.Швець С.В. Характеристика та вихідна інструментальна поверхня у процесі формоутворення // Вісник Сумського державного університету. Серія Технічні науки. - 2012. № 4. - C. 162-167.

13.Щеголев А. В. Конструирование протяжек / А. В. Щеголев - Ленинград: Машгиз, 1960. $-352 \mathrm{c}$

14.Маргулис Д. К. Протяжки для обработки отверстий / Д. К. Маргулис, М.М. Тверской, В. Н. Ашихмин и др. - Москва: Машиностроение, 1986. - 232 с.

15.Akula M. Design and analysis of broach tool for splines / Malyadri Akula, K.Chandra Sekhar, A. Nagendra. - International Journal of Advanced Engineering Technology, vol. IV, 2013. - Pp. 06 08 .

16. Vogtel P. Automatic Broaching Tool Design by Technological and Geometrical Optimization / P. Vogtel, F. Klocke, D. Lung, S. Terzi. - Procedia CIRP 33, 2015. - Pp. 496 - 501.

17. Vogtel P. Modelling of process forces in broaching Inconel 718 / P. Vogtel, F. Klocke, H. Puls, S. Buchkremer, D. Lung. - Procedia CIRP 8, 2013. - Pp. 409 - 414.

Швец С. В., к.т.н.

Сумский государственный университет

\section{ВЛИЯНИЕ СХЕМЫ РЕЗАНИЯ И МЕТОДА ФОРМООБРАЗОВАНИЯ НА КОНСТРУКЦИЮ РЕЖУЩЕГО ИНСТРУМЕНТА}

В проиессе резания решаются две задачи - удаление припуска и формирование поверхности детали с необходимыми параметрами качества. Это требует определения схемы резания и метода образования поверхности детали. В настоящее время в литературе нет однозначного определения этих понятий. В работе, в первую очередь, уделено внимание этой проблеме. Также показано, что исходная инструментальная поверхность может быть реальной поверхностью, которая ограничивает калибрувальную часть инструмента и на которой находятся формообразующие режущие кромки или их участки, контактирующие с поверхностью детали. А может образовываться движениями режущих кромок 6 пространстве, то есть кинематически. Припуск может разделяться на слои поверхностями, окутываюшими поверхность детали с последующим измельчением каждого такого слоя, или поверхностями, которые пересекают поверхность детали с последующим разделением их на стружку. Методов формообразования лезвийным инструментом также может быть два. 
Это либо линейный контакт, либо точечный. Схемы резания и методы формообразования в сочетании с относительныли движениями инструмента и детали и воображением инженера-конструктора создают широкие возможности для образования различных видов и типов режущих инструментов.

Ключевые слова: схема, метод, формообразование, припуск, деталь, контакт, лезвие

\section{Shvets S. V., Ph.D.}

Sumy State University

\section{INFLUENCE OF CUTTING SCHEME AND METHOD OF FORMATION ON THE DESIGN OF THE EDGE TOOL}

In the process of cutting two problems are solved - removal of the lowering and forming of the surface of the part with the necessary quality parameters. This requires the definition of the cutting scheme and the method of forming the surface of the part. At this time in the literature there is no definite definition of these concepts. In the work, first of all, attention is paid to this problem. It is also shown that the original tool surface may be a real surface that restricts the calibration part of the tool and which is shaping cutting edges or their parts that come in contact with the surface of the part. And it can be formed by the movements of the cutting edges in space, that is, kinematically. The allowance can be divided into layers by surfaces that cover the surface of the part with the subsequent shredding of each such layer, or surfaces that cross the surface of the part, then dividing them into chips. Methods of shaping a blade tool can also be two. This is either a linear contact, or a point. Schemes of cutting and methods of forming together with the relative movements of the tool and the details and imagination of the design engineer create wide opportunities for the formation of different types and types of cutting tools.

Key words: scheme, method, formation, release, detail, contact, blade 